usually harmless to their human hosts. The pathogenic types which do invade the genital tract have therefore been conveyed to it from some outside source, for example, the respiratory tract, either of the mother or that of her attendants: familial sources have been incriminated in not a few instances. The results and lessons of that work, if rightly applied, should achieve a reduction in the incidence of hæmolytic streptococcus infection following childbirth.

In conclusion, reference may be made to the work of the Department of Biological Standards at the National Institute for Medical Research. Standards for gas gangrene antitoxins (vibrion septique and $B$. oedematiens), staphylococcus antitoxin and antipneumococcus serum (Types I and II) have been brought into official use under the
Therapeutic Substances Act. A new sample of diphtheria antitoxin standard has been prepared. The British standard for pituitary posterior lobe extract has now been adopted formally for international use. The Institute has also accepted responsibility for the preparation and distribution of the international standards for the arsphenamine group of drugs. New standards for a number of other compounds have been adopted for international use and have been distributed, or will be distributed as soon as prepared, namely, insulin, the vitamins (A, C and D) and the sex hormones (œstradiol benzoate, androsterone and progesterone). The supply of progesterone is being undertaken by the Institute : it is being prepared from pregnandiol and stigmasterol, and extracted from the corpora lutea of whales.

\title{
Obituary
}

\section{Dr. Arthur Eastwood}

$\mathrm{O}^{\mathrm{N}}$ May 6, after a few hours of illness, Arthur Eastwood, formerly of the Laboratory of the Ministry of Health, died in London in his sixty-ninth year. He was born in Manchester, was educated in its Grammar School and graduated in Lit. Hum. at Oxford in 1893. Deeply read in moral philosophy, with the Bar as the obvious place for his acute intellect and power of lucid exposition, Eastwood at this time fell under the spell of Michael Foster as the 'philosopher in medicine', migrated to Cambridge to sit at Foster's feet and finally qualified M.D. (London) in 1902, after clinical studies at St. Bartholomew's Hospital. His distinguished work in the histology of malignant tumours led the Royal Commission on Tuberculosis to invite him to examine its experimental material. At the Commission's experimental farm in Stansted, Essex, in 1902-9, Eastwood spent seven busy and happy years, making with Cobbett and the brothers Griffith a highly successful 'team', one of the first to show how valuable team-work can be in ad hoc research.

The Commission's final report left undecided the question of tubercle bacilli of bovine origin as the cause of tuberculosis in children and, in 1909, Eastwood, at Newsholme's suggestion, was given the post of Inspector to the Local Government Board and asked to establish for the Board its first pathological laboratory, with the duty of investigating this question. The Board's laboratory, later the Laboratory of the Ministry of Health, begun thus as an almost accidental afterthought, developed under Eastwood's direction into a valued branch of the Ministry's medical department. Its activities were recounted and accorded due recognition in the Annual Report of the Chief Medical Officer for 1932. They can be summarised as studies in the bacteriology of epidemics, ranging from bubonic plague (the epizootic in East Anglia in 1910) and cerebrospinal fever (the epidemies of the War years) to pneumococcus and streptococcus infections and directing attention to the significance, practical and theoretical, of serological 'types' in pathogenic bacterial species.

In all these researches Eastwood's clear vision and gift of lucid expression were put at the service of his colleagues. He himself, though, of course, convinced of the prime necessity of experiment in scientific medicine, felt his own true bent to be the philosophical examination of first principles, the synthesis of experimental data into theory and the enunciation of hypotheses worthy of experimental test. A long series of articles, published as Reports to the Ministry or in the Journal of Hygiene, was the result. In these, he discussed infection and immunity as parts of the physiology of bacterial cells on one hand and animal hosts on the other. His method was almost Socratic in its simplicity and reliance on pure logic: his articles, whatever may be their ultimate value in advancing knowledge, will continue to delight all who take pleasure in intellectual disquisition. Perhaps the most notable example is his treatment of bacterial variation and transmissible autolysis (Reports on Pub. Health and Med. Subjects, 1923, No. 18) in which he put forward the hypothesis of non-viable mutants as the explanation for the phenomena associated with bacteriophage.

Eastwood's three years of leisure after retirement were devoted to the preparation of a conspectus of immunity in general; he felt that the importance of a unifying hypothesis for the great body of dis. parate data was not sufficiently appreciated by postEhrlich pathologists. It is to be hoped that this had reached a stage permitting of its publication as a final example of Eastwood's method. 